\title{
Retention of oral microorganisms on conventional and resin-modified glass-ionomer cements
}

\section{Retenção de microrganismos bucais em cimentos de ionômero de vidro convencionais e modificados por resina}

\author{
Denise PEDRINI* \\ Elerson GAETTI-JARDIM JÚNIOR* \\ Andréia Coelho de VASCONCELOS**
}

\begin{abstract}
PEDRINI, D.; GAETTI-JARDIM JÚNIOR, E.; VASCONCELOS, A. C. de. Retention of oral microorganisms on conventional and resin-modified glass-ionomer cements. Pesqui Odontol Bras, v. 15, n. 3, p. 196-200, jul./set. 2001.

Secondary caries are a worldwide public and socioeconomic problem. The placement of restorations can lead to the development of environmental conditions favorable to microbial colonization, especially on the tooth/restoration interface, which is a predisposing factor for secondary caries. The aim of this study was to evaluate microbial retention on conventional (Chelon-Fil and Vidrion R) and resin-modified (Vitremer and Fuji II LC) glass-ionomer cements, in situ, using a hybrid composite resin (Z100) as a control. Twelve volunteers wore Hawley appliances with specimens made of all tested filling materials for 7 days. The specimens were then removed from the appliances and transferred to tubes containing $2.0 \mathrm{ml}$ of Ringer-PRAS. Microorganisms from the samples were inoculated onto blood agar and Mitis Salivarius Bacitracin agar and incubated under anaerobiosis $\left(90 \% \mathrm{~N}_{2}, 10 \% \mathrm{CO}_{2}\right)$, at $37^{\circ} \mathrm{C}$, for 10 and 2 days, respectively. The resin-modified glass-ionomer cements and the composite resin retained the same levels of microorganisms on their surfaces. The resin-modified glass-ionomers retained less mutans streptococci than the composite resin and conventional glass-ionomer cements. The conventional glass-ionomer cements retained less mutans streptococci than the composite resin, but that difference was not statistically significant.
\end{abstract}

UNITERMS: Dental caries; Dental plaque; Glass-ionomer cements.

\section{INTRODUCTION}

The colonization of surfaces of restorations by cariogenic bacteria can contribute to increase the incidence of secondary caries ${ }^{25}$, which is one of the major reasons for replacement of restorations ${ }^{18}$. This fact is even more complicated when the restoration is placed on cervical areas, where the retention of bacterial biofilm can also compromise gingival health.

Due to their physical, chemical and biological properties, glass-ionomer cements have been used as lining, luting and filling materials, especially for restoring cervical areas ${ }^{6}$ Resin-modified glass-ionomer cements have shown improved properties, including faster setting, as well as less sensitivity to hydration and dehydratation ${ }^{9}$.

The surfaces of conventional glass-ionomer cements remain relatively rough, even with careful polishing ${ }^{6,20}$. This might enhance the accumulation of bacterial biofilm on glass-ionomer restorations, leading to gingival inflammation ${ }^{6}$.

The bacterial plaque located on the surface of glass-ionomer fillings shows a number of microorganisms similar to that of the plaque observed on composite resin restorations, however, the levels of mutans streptococci are lower ${ }^{24}$. This phenomenon may be related to fluoride release and to the effect of this ion on many metabolic processes in bacteria ${ }^{26}$.

There appear to be few reports on the effects of resin-modified glass-ionomer cements - which permit an improvement of finishing and polishing ${ }^{16}$ - on the surrounding microbiota, especially regarding the levels of mutans streptococci. Therefore, the aim of this study was to evaluate, in situ, microbial retention on conventional and resin-modified glass-ionomer cements.

${ }^{*} \mathrm{PhD},{ }^{* *} \mathrm{DDs}-\mathrm{School}$ of Dentistry of Araçatuba - UNESP. 
PEDRINI, D.; GAETTI-JARDIM JÚNIOR, E.; VASCONCELOS, A. C. de. Retention of oral microorganisms on conventional and resin-modified glass-ionomer cements. Pesqui Odontol Bras, v. 15, n. 3, p. 196-200, jul./set. 2001.

\section{MATERIALS AND METHODS Dental materials}

Two conventional glass-ionomer cements, Chelon-Fil (Espe GmbH, Germany) and Vidrion R (SS White, Brazil), and two resin-modified glass-ionomer cements, Vitremer (3M Dental Products, Brazil) and Fuji II LC (GC, Japan), were studied. The hybrid composite resin Z100 (3M Dental Products, Brazil) was used as a control.

Specimens were prepared with each material according to their manufacturers' instructions. The materials were placed into cavities (diameter of $5 \mathrm{~mm}$, depth of $1 \mathrm{~mm}$ ) on the outer surface of the palate of Hawley appliances. Twelve specimens were prepared with each material. The glass-ionomer specimens were covered with the light-curing bonding resin Probond (Dentsply, Brazil) and stored at $100 \%$ relative humidity after preparation, in order to avoid changes on their surfaces. After 24 hours, all specimens were polished $^{11}$ using sequential Sof-Lex discs (3M Dental Products, Brazil) ${ }^{20}$. An acrylic net was used to cover the specimens so as to avoid the autocleaning produced by the movements of the tongue, thus, simulating the conditions of interproximal and cervical areas of teeth.

\section{Experimental design}

Twelve 17-23-year-old volunteers participated in this study. All were students of the School of Dentistry of Araçatuba - UNESP. All students received oral hygiene instructions (flossing and tooth brushing) before the experimental essay.

The volunteers wore the Hawley appliances for 7 days. During the experimental period, the volunteers were allowed to brush their teeth with the Hawley appliances removed from their mouth, but were not allowed to use a toothpaste or any chemical compound with fluoride or other substance

TABLE 1 - Number of microorganisms recovered from the glass-ionomer cements and the composite resin.

\begin{tabular}{c|c}
\hline \hline Material & Mean levels $\left(10^{3}\right.$ CFU $)$ \\
\hline Z100 & $51.54 \mathrm{a}$ \\
\hline Fuji II LC & $80.05 \mathrm{ab}$ \\
\hline Vitremer & $69.83 \mathrm{ab}$ \\
\hline Vidrion R & $271.15 \mathrm{~b}$ \\
\hline Chelon-Fil & $157.52 \mathrm{~b}$ \\
\hline \hline
\end{tabular}

Different letters indicate statistical difference at the level of $1 \%$. with antimicrobial properties. During the meals, the Hawley appliances were stored at $100 \% \mathrm{hu}-$ midity.

After this period, the specimens on the Hawley appliances were removed and transferred to tubes containing $2.0 \mathrm{ml}$ of pre-reduced anaerobically sterilized Ringer solution ${ }^{21}$ under $\mathrm{CO}_{2}$ flux.

All samples were taken to the laboratory, subjected to serial ten-fold dilutions ${ }^{29}$ in Ringer-PRAS, and cultured onto brain heart infusion agar (Difco) supplemented with yeast extract $(0.5 \%)$, hemin $(0.5 \mathrm{mg} / \mathrm{ml})$, menadione $(5 \mathrm{mg} / \mathrm{ml})$ and $5 \%$ defibrinated sheep blood (blood agar) - for the isolation of fastidious microorganisms and determination of total bacterial count -, as well as on Mitis Salivarius Bacitracin agar ${ }^{10}$ (MSB agar) - to recover mutans streptococci, in duplicate. The blood agar and MSB agar plates were incubated under anaerobiosis $\left(90 \% \mathrm{~N}_{2}, 10 \% \mathrm{CO}_{2}\right)$, at $37^{\circ} \mathrm{C}$, for 10 and 2 days, respectively.

Identification of mutans streptococci was carried out through the analysis of the morphology of cells (Gram) and colonies, as well through the analysis of the fermentation of manitol and sorbitol ${ }^{4}$. The differences in the levels of mutans streptococci and in the total number of viable bacterial cells on conventional glass ionomer cement, resin-modified glass-ionomer cement and composite resin were determined through the KruskalWallis test.

\section{RESULTS}

The results are presented in Tables 1 and 2. Table 1 presents the total number of microorganisms recovered from the samples, whereas Table 2 shows the levels of mutans streptococci isolated from the specimens.

The resin-modified glass-ionomer cements and the composite resin showed lower levels of micro-

TABLE 2 - Levels of mutans streptococci on the tested materials.

\begin{tabular}{c|c}
\hline \hline Material & Mean levels $\left(10^{3} \mathrm{CFU}\right)$ \\
\hline Z100 & $16.62 \mathrm{~b}$ \\
\hline Fuji II LC & $2.40 \mathrm{a}$ \\
\hline Vitremer & $1.81 \mathrm{a}$ \\
\hline Vidrion R & $6.00 \mathrm{~b}$ \\
\hline Chelon-Fil & $5.01 \mathrm{~b}$ \\
\hline \hline
\end{tabular}

Different letters indicate statistical difference at the level of $5 \%$. 
PEDRINI, D.; GAETTI-JARDIM JÚNIOR, E.; VASCONCELOS, A. C. de. Retention of oral microorganisms on conventional and resin-modified glass-ionomer cements. Pesqui Odontol Bras, v. 15, n. 3, p. 196-200, jul./set. 2001.

organisms than the conventional glass-ionomer cements, even though statistical significance was observed only between the composite resin and the conventional glass-ionomer cements $(p=0.01)$. The resin-modified glass-ionomer cements presented lower numbers of mutans streptococci than the other tested materials $(\mathrm{p}=0.05)$. There were no significant differences between conventional glass-ionomer cements and the composite resin.

\section{DISCUSSION}

Although the clinical use of glass-ionomer cements has increased due to their properties, such as fluoride release and adhesion to dental tissues ${ }^{6,7,19}$, these materials have deficiencies. For instance, their surface is rough in comparison to that of composite resins, which can enhance microbial retention and plaque accumulation ${ }^{6,22}$.

The resinous content of resin-modified glass-ionomer cements, while improving their physical properties ${ }^{15}$, can also reduce plaque accumulation, preventing secondary caries. The number of microorganisms recovered from resin-modified ionomer specimens was similar to that recovered from composite resin samples, and it was lower than the microbial levels found on conventional glass-ionomer cements. However, the differences between conventional and resin-modified glass-ionomer cements were not statistically significant (Table 1).

The glass-ionomer cements, particularly the resin-modified ionomers (Table 2), showed smaller numbers of mutans streptococci than the composite resin, and these results are in agreement with those presented by SVANBERG et al. ${ }^{24}$ (1990) and BERG et al. ${ }^{2}$ (1990). According to BERG et al. ${ }^{2}$ (1990), the number of mutans streptococci on restorative materials stabilized three months after the treatment, probably due to the decrease of fluoride release from ionomer restorations. However, VAN DIJKEN et al. ${ }^{28}(1991)$ did not report these differences.

The glass-ionomer cements can interfere with the growth of cariogenic bacteria, as shown by BERG et al. ${ }^{2}$ (1990) and GARIB et al. ${ }^{8}$ (1993). The presence of a less cariogenic microflora on these cements might be due to fluoride release ${ }^{3}$, suggesting that the resinous content of resin-modified glass-ionomers fillings does not interfere substantially with fluoride release $\mathrm{e}^{5,27}$.

Since the levels of fluoride release in glass-ionomer cements decreased over time ${ }^{1,7}$, the effects of these materials on the microbiota might vary at the same extension. However, even in sublethal concentrations, fluoride is able to produce remarkable effects on the acidogenicity and adhesion ability of mutans streptococci ${ }^{13,23}$. It can reduce the production of glucan polymers ${ }^{30}$, inhibit glycolysis ${ }^{14}$ and other metabolic pathways, preventing the colonization of dental tissues ${ }^{17}$, and affecting the activity of enzymes associated with the citoplasmatic membrane ${ }^{12}$. Therefore, it is possible that mutans streptococci isolated from specimens made of conventional and resin-modified glass-ionomers present lower metabolic activity than those strains isolated from specimens made of hybrid resin (Z100).

The lack of significant differences between the conventional glass-ionomer cements and the composite resin (Z100) as to the levels of mutans streptococci might reflect the greater roughness of conventional ionomers, although careful polishing was carried out ${ }^{6,20}$. That roughness might decrease the advantageous effects produced by fluoride release.

Interactions between restorative materials and oral microflora can produce different environments, which could lead to conditions suitable to the development of dental caries, or maintenance of oral health. These factors must be considered in the choice of a dental material.

\section{CONCLUSIONS} that:

On the basis of this study, it can be concluded 1. Conventional glass-ionomer cements (Vidrion $R$ and Chelon-Fil) retained a greater number of microorganisms than the hybrid resin (Z100).

2 . The levels of microorganisms retained on the surface of resin-modified glass-ionomers (Vitremer and Fuji II LC) were similar to those observed on composite resin (Z100) samples.

3. Resin-modified glass-ionomers (Vitremer and Fuji II LC) retained less mutans streptococci than the resin (Z100) and the conventional glass-ionomer cements (Vidrion $\mathrm{R}$ and Chelon-Fil).

\section{ACKNOWLEDGMENTS}

We would like to thank Professor Eloi Dezan Júnior for the statistical analysis, and Maria dos Santos Ferreira Fernandes and Mario Luis da Silva for the preparation of the Hawley appliances utilized in this work. 
PEDRINI, D.; GAETTI-JARDIM JÚNIOR, E.; VASCONCELOS, A. C. de. Retention of oral microorganisms on conventional and resin-modified glass-ionomer cements. Pesqui Odontol Bras, v. 15, n. 3, p. 196-200, jul./set. 2001.

PEDRINI, D.; GAETTI-JARDIM JÚNIOR, E.; VASCONCELOS, A. C. de. Retenção de microrganismos bucais em cimentos de ionômero de vidro convencionais e modificados por resina. Pesqui Odontol Bras, v. 15, n. 3, p. 196-200, jul./set. 2001.

A cárie secundária representa problema de saúde pública e socioeconômico no mundo. A restauração de dentes acometidos por cárie pode criar condições favoráveis à proliferação microbiana na superficie do material restaurador ou na interface dente/restauração, criando ambiente propício para o estabelecimento de cárie secundária. O objetivo deste estudo foi avaliar a capacidade de retenção de placa bacteriana em cimentos de ionômero de vidro convencionais (Chelon-Fil e Vidrion R) e modificados por resina (Vitremer e Fuji II LC) e de resina composta híbrida (Z100), utilizada como controle. Nos testes de retenção de microrganismos, in situ, 12 voluntários utilizaram, por 7 dias, placa de Hawley contendo corpos-de-prova de todos os materiais. A seguir, os corpos-de-prova foram transferidos para tubos contendo 2,0 $\mathrm{ml}$ de Ringer-PRAS e os microrganismos presentes em sua superficie foram cultivados em placa com ágar-sangue e ágar Mitis Salivarius Bacitracina, os quais foram incubados, a $37^{\circ} \mathrm{C}$, em anaerobiose $\left(90 \% \mathrm{~N}_{2}, 10 \%\right.$ $\mathrm{CO}_{2}$ ), por 10 e 2 dias, respectivamente. Os ionômeros modificados por resina retiveram quantidade de bactérias similar àquela mostrada pela resina testada. Os ionômeros modificados por resina também apresentaram menor número de estreptococos do grupo mutans do que a resina e os cimentos ionoméricos convencionais. Os ionômeros de vidro convencionais apresentaram menor número de estreptococos do grupo mutans que a resina, sendo que essa diferença não foi estatisticamente significativa.

UNITERMOS: Cárie dentária; Placa dentária; Cimentos de ionômero de vidro.

\section{BIBLIOGRAPHIC REFERENCES}

1. ARAUJO, F. B.; GARCÍA-GODOY, F.; CURY, J. A.; CONCEIÇÃO, E. N. Fluoride release from fluoride-containing materials. Oper Dent, v. 21, n. 5, p. 185-190, Sept./Oct. 1996.

2. BERG, J. H.; FARRELL, J. E.; BROWN, L. R. Class II glass ionomer/silver cermet restorations and their effect on interproximal growth of mutans streptococci. Pediatr Dent, v. 12, n. 1, p. 20-23, Feb. 1990.

3. CARDoso, D. C.; MARTÍNEZ, B. G.; BAÑos, I. A. et al. Efecto del fluoruro liberado a partir de ionómero de vidrio sobre Streptococcus mutans. Rev ADM, v. 51, n. 5, p. 285-287, Sept./Oct. 1994.

4. COLliNA, E.; MOREIRA, M.; BARBOSA, A. D. Comparação da ação do verniz fluoretado Duraphat e do cariostático Bioride (diamino fluoreto de prata $12 \%$ ), sobre a contagem de Streptococcus do grupo mutans, em crianças com dentição decídua. Rev ABO Nac, v. 8, n. 1, p. 14-20, fev./mar. 2000.

5. DUNNE, S. M.; GOOLNIK, J. S.; MILLAR, B. J.; SEDDON, R. P. Caries inhibition by a resin-modified and a conventional glass ionomer cement, in vitro. J Dent, v. 24, n. 1-2, p. 91-94, Jan./Mar. 1996.

6. FORSS, H.; SEPPÄ, L.; ALAKUIJALA, P. Plaque accumulation on glass ionomer filling materials. Proc Finn Dent Soc, v. 87, n. 3, p. 343-350, 1991.

7. FORSTEN, L. Short- and long-term fluoride release from glass ionomers and other fluoride-containing filling materials in vitro. Scand J Dent Res, v. 98, n. 2, p. 179-185, Apr. 1990.

8. GARIB, T. M.; ROSA, O. P. S.; ROCHA, R. S. S. Ação antimicrobiana de cimentos de ionômero de vidro restauradores. Rev Fac Odontol Bauru, v. 1, n. 1-4, p. 1-5, jan./dez. 1993.

9. GLADYS, S.; van MEERBEEK, B.; BRAEM, M. et al. Comparative physico-mechanical characterization of new hybrid restorative materials with conventional glass-ionomer and resin composite restorative materials. J Dent Res, v. 76, n. 4, p. 883- 894, Apr. 1997.

10. GOLD, O. G.; JORDAN, H. V.; van HOUTE, J. A selective medium for Streptococcus mutans. Arch Oral Biol, v. 18 , n. 11 , p. 1357-1364, Nov. 1973.

11. GUIDE to the use of glass ionomer filling materials. Féderation Dentaire Internationale. Technical Report $n^{\circ} 27$. Int Dent J, v. 37, n. 3, p. 183-184, Sept. 1987.

12. HAMILTON, I. R. Biochemical effects of fluoride on oral bacteria. J Dent Res, v. 69 (special issue), p. 660-667, Feb. 1990.

13. IZAGUIRRE-FERNANDEZ, E. J.; EISENBERG, A. D.; CURZON, M. E. Interaction of zinc with fluoride on growth, glycolysis and survival of Streptococcus mutans GS-5. Caries Res, v. 23, n. 1, p. 18-25, 1989.

14. KAUFMANN, M.; BARTHOLMES, P. Purification, characterization and inhibition by fluoride of enolase from Streptococcus mutans DSM 320523. Caries Res, v. 26, n. 2, p. 110-116, 1992.

15. KIM, Y. G.; HIRANO, S.; HIRASAWA, T. Physical properties of resin-modified glass-ionomers. Dent Mater J, v. 17, n. 1, p. 68-76, Mar. 1998.

16. LEINFELDER, K. F. Glass ionomers are still necessary. Esthet Dent Update, v. 5, n. 6, p. 151, 1994.

17. MEURMAN, J. H. Effect of sodium and amine fluoride treatment on adsorption and ultrastructure of S. mutans and $S$. sanguis. Scand J Dent Res, v. 95, n. 5, p. 389-396, Oct. 1987.

18. MJÖR, I. A. Frequency of secondary caries at various anatomical locations. Oper Dent, v. 10, n. 3, p. 88-92, Summer 1985.

19. MOUNT, G. J. Restoration with glass-ionomer cement: requirements for clinical success. Oper Dent, v. 6, n. 2, p.59-65, Spring 1981.

20. PEDRINI, D. Estudo comparativo da rugosidade superficial entre cimentos de ionômero de vidro e compômero: efeito de material, técnica de acabamento/polimento e tempo. Araraquara, 1998. 195 p. Tese 
PEDRINI, D.; GAETTI-JARDIM JÚNIOR, E.; VASCONCELOS, A. C. de. Retention of oral microorganisms on conventional and resin-modified glass-ionomer cements. Pesqui Odontol Bras, v. 15, n. 3, p. 196-200, jul./set. 2001.

(Doutorado) - Faculdade de Odontologia de Araraquara, Universidade Estadual Paulista.

21. SLOTS, J. Selective medium for Actinobacillus actinomycetemcomitans. J Clin Microbiol, v. 15, n. 4, p. 606-609, Apr. 1982.

22. SMALES, R. J. Plaque growth on dental restorative materials. J Dent, v. 9, n. 2, p. 133-140, June 1981.

23. SVANBERG, M.; KRASSE, B.; ÖRNERFELDT, H. O. Mutans streptococci in interproximal plaque from amalgam and glass ionomer restorations. Caries Res, v. 24, n. 2, p. 133-136, 1990.

24. SVANBERG, M.; MJÖR, I. A.; ORSTAVIK, D. Mutans streptococci in plaque from margins of amalgam, composite, and glass-ionomer restorations. J Dent Res, v. 69, n. 3, p. 861-864, Mar. 1990.

25. TAYLOR, M. J.; LYNCH, E. Microleakage. J Dent, v. 20, n. 1, p. 3-10, Feb. 1992.

26. TEN CATE, J. M. Current concepts on the theories of the mechanism of action of fluoride. Acta Odontol Scand, v. 57, n. 6, p. 325-329, Dec. 1999.

27. TORABZADEH, H.; ABOUSH, Y. E. Y.; LEE, A. R. Comparative assessment of long-term fluoride release from light-curing glass-ionomer cements. J Dent Res, v. 73, n. 4, p. 853, Apr. 1994.

28. van DIJKEN, J.; PERSSON, S.; SJÖSTRÖM, S. Presence of Streptococcus mutans and lactobacilli in saliva and on enamel, glass ionomer cement, and composite resin surfaces. Scand J Dent Res, v. 99, n. 1, p. 13-19, Feb. 1991.

29. YAMAMOTO, K.; NODA, H.; KIMURA, K. Adherence of oral streptococci to composite resin restorative materials. $\mathbf{J}$ Dent, v. 17, n. 5, p. 225-229, Oct. 1989.

30. ZAMECK, R. L.; TINANOFF, N. Effects of $\mathrm{NaF}$ and $\mathrm{SnF}_{2}$ on growth, acid and glucan production of several oral streptococci. Arch Oral Biol, v. 32, n. 11, p. 807-810, 1987.

\section{Scientific Electronic Library Online Sci Ehto Parceria: FAPESP/BIREME}

SciELO - Scientific Electronic Library Online é uma coleção eletrônica de revistas científicas disponíveis na Internet. A coleção traz os textos completos de artigos científicos, bases de dados e relatórios de uso e de impacto da literatura científica publicada no site.

Em operação desde 1997, atualmente estão disponíveis 29 revistas brasileiras nas áreas de ciências biológicas e da saúde, ciências sociais e humanas, ciências agrárias, física etc. Novas publicações são incluídas regularmente em várias especialidades.

Entre as revistas de nossa coleção, está a Pesquisa Odontológica Brasileira.

\section{Consulte a Pesquisa Odontológica Brasileira (Revista de Odontologia da USP) na SciELO - http://www.scielo.br/rousp}

